\title{
A QUANTITATIVE RISK ASSESSMENT STUDY FOR THE LIKELIHOOD OF INTRODUCTION OF NEW FMDV THROUGH IMPORTATION OF CATTLE FROM SUDAN TO EGYPT: AN EDIFICATION ARTICLE
}

\author{
AHMED M BYOMI \\ Dept. of Hygiene and Zoonoses, Fac. of Vet. Medicine, University of Sadat City \\ Email: ahmedbayaumi603@yahoo.com
}

ABSTRACT

Received at: $10 / 7 / 2014$

Accepted: 20/9/2014
FMD is an endemic disease in Egypt, with serotypes $\mathrm{O}$ and A considered to circulate continuously. In 2006, a novel type A strain, genetically related to the sub-saharan African Group VII topotype, entered Egypt and rapidly spread throughout cattle and buffalo population, causing severe losses and becoming endemic. During February 2012, a great number of FMD events were reported throughout Egypt despite a nationwide vaccination campaign in January 2012. The emergence of these FMDv strains to Egypt was always associated with importation or smuggling of cattle or other ruminants from the neighbor countries. This article is an edification article focuses on the risks associated with importation of cattle infected with new strain of FMDv from Sudan to Egypt.

Key words: FMD, Importation, Edification article

\section{INTRODUCTION}

FMD reduces investment and development of the livestock sector in many developing countries as well as export trade opportunities and global food supply (Paton et al., 2009). Several outbreaks of the disease affected cattle, buffaloes, sheep and goats with the predominant isolated serotype O1 (Moussa et al., 1974; Daoud et al., 1988 and El-Nakashly et al., 1996). Furthermore, Abd El-Hakim and Abd ElRahim (2000) identified FMD virus serotypes A and $\mathrm{C}$, which were not recorded previously in Egypt. In 2006, severe outbreak was recognized in Ismaillia and FMDV type A was confirmed from the clinical cases (Knowles et al., 2007 and El-Trabili et al., 2009). The epizootic form of FMD reported in Egypt (2012) was due to (FMD) serotype SAT2. The disease was reported in both Egypt and Libya between February and March 2012 (Lockhart et al., 2012). The emergence of FMD SAT2 outbreaks in both countries originating probably from different sources and may be linked to trade of animals from East Africa (Berrada, 2012). This article focuses on the risks associated with trade in cattle from probably infected zones in Sudan. Quantitative estimates of the risk, the spatial variation in the risk, and the factors associated with the risk for FMDV introduction into a country are a prerequisite for the development of differential policies for prevention and eventual control of epidemics (Martınez-Lopez et al., 2008). This article presents a Quantitative assessment of the risks of a new FMDv strain introduction into Egypt through importation of cattle from Sudan.

\section{Overall objective:}

- Prevention of severe losses in cattle populations in Egypt and public fears regarding the outbreaks of FMD due to new serotypes of FMD virus introduced into Egypt from Sudan.

\section{Overall objective:}

- Prevention of the economic losses at the national and farmers levels due to subsequent outbreaks of FMD.

\section{General Objectives:}

1- Direct attention of the Veterinary authorities in Egypt to the possible risk pathways associated with importation of live stock cattle from Sudan to prevent introduction of a new strain of the FMDv.

2- To assist the Egyptian veterinary authorities in developing strategies and specific actions based on the SPS measures to be implemented on introducing cattle from Sudan. 
Problem Identification:

\begin{tabular}{ll}
\hline Egypt population 2009 & $\mathbf{8 3}$ Million \\
\hline GDP - current prices (US dollars/2009) & S188 billion \\
\hline GDP per capita (2009) & $\begin{array}{l}\text { S2.380 or S6.000 on a purchasing power parity } \\
\text { basis }\end{array}$ \\
\hline Imports (2009) & S44.0 billion \\
\hline Total food and agriculture imports (2009) & $\mathbf{S 1 0 . 9}$ billion \\
\hline
\end{tabular}

Source: (European commission for control foot and mouth disease, 2012) Virtually Egypt's entire livestock herd, both cattle and buffalo, is maintained primarily for dairy production and meat production of secondary importance. This is due to the absence of beef breeds. All cattle herds consist of either mixed.

\begin{tabular}{ll}
\hline Egyptian beef production in MY 2013 & $\mathbf{2 8 5 , 0 0 0 ~ M T ~}$ \\
\hline Egyptian beef production in MY 2012 & 280,000 MT \\
\hline Egyptian beef production in MY 2011 & 312,000 MT \\
\hline
\end{tabular}

Source: (European commission for control foot and mouth disease, 2012)

Egyptian beef production in MY 2013 will reach 285,000 MT, up roughly 5,000 MT or slightly below $2 \%$ from MY 2012 levels. The increase in total animal slaughter is due to the gradual recovery of calf production. However, beef production in MY 2013 will still be down from the MY 2011 level of 312,000 MT due to the lingering effects of the FMD-SAT2 outbreak. Egypt will bridge the gap between low domestic beef production and demand through imports (Gain Report, Global Agricultural Information Network, 2012).

Egyptian Cattle Production:

\begin{tabular}{|c|c|c|c|}
\hline $\begin{array}{l}\text { Animal numbers, cattle, } \\
\text { Egypt }\end{array}$ & 2011 & 2012 & 2013 \\
\hline Total cattle stocks & $6,100,000$ & $6,175,000$ & $6,180,000$ \\
\hline Dairy cattle stocks & $3,885,000$ & $3,960,000$ & $3,980,000$ \\
\hline Beef cows stocks & $\mathbf{0}$ & $\mathbf{0}$ & $\mathbf{0}$ \\
\hline Production (calf crop) & $1,700,000$ & $1,600,000$ & $1,620,000$ \\
\hline Total imports & 70,000 & 95,000 & $\mathbf{1 0 0 , 0 0 0}$ \\
\hline Total exports & $\mathbf{0}$ & $\mathbf{0}$ & $\mathbf{0}$ \\
\hline Cow slaughter & 300,000 & 300,000 & 340,000 \\
\hline Calf slaughter & 90,000 & 60,000 & 80,000 \\
\hline Loss & 235,000 & 550,000 & 300,000 \\
\hline
\end{tabular}

Sources: Ministry of Agriculture and Land Reclamation, industry Egypt and FAS Cairo. 
Egyptian beef Production and consumption:

\begin{tabular}{lllll}
\hline $\begin{array}{l}\text { Meat, beef } \\
\text { veal, Egypt }\end{array}$ & and & 2011 USDA official & 2012 USDA official & 2013 USDA official \\
\hline Slaughter & 1,460 & 1,300 & 1,340 & 1000 head \\
\hline Beginning stock & 0 & 0 & 0 & 1000 MT \\
\hline Production & 312 & 280 & 285 & 1000 MT \\
\hline Total Import & 217 & 230 & 225 & 1000 MT \\
\hline $\begin{array}{l}\text { Supply } \\
\text { Total export }\end{array}$ & 529 & 510 & 510 & 1000 MT MT \\
\hline $\begin{array}{l}\text { Human domestic } \\
\text { consumption }\end{array}$ & 525 & 0 & 0 & $1000 \mathrm{MT}$ \\
\hline
\end{tabular}

Sources:Ministry of Agriculture and Land Reclamation, industry sources, and FAS Cairo (2012).

Consumption and Consumer Preferences:

Egyptians prefer fresh beef to other types of animal protein such as poultry and lamb. However, higher beef prices in MY 2012 and consumer fears of contracting FMD detrimentally influenced beef consumption. Poultry and fish prices benefited from consumers shifting to other protein.

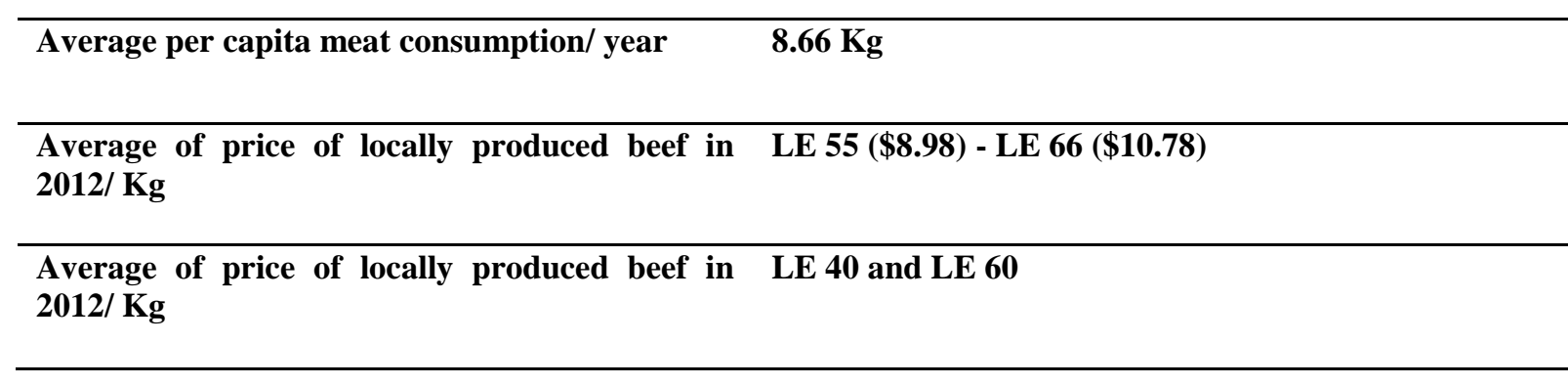

Source: (Gain Report, Global Agricultural Information Network, 2012).

Industry and government sources report that livestock owners remain fearful of the further spread of FMD in MY 2012/13. This fear factor is providing an incentive to push animals to market earlier than anticipated, even if this means at lower weights compared to historical levels. Further compounding the situation are high feed prices. This will similarly motivate livestock owners to send to market animals at below ideal slaughter weight.

\section{Impact of Foot-and-Mouth Disease:}

The FMD-SAT2 strain broke out in February 2012. The Ministry of Agriculture and Land Reclamation confirms that by August 2012, some 94,401 animals have been infected. The mortality rate is $28 \%$ or 26,245 head, a loss of LE 200 million (\$33 million).

The Egyptian herd numbers 6 million head comprised of half cattle and half buffalo. Due to lower than anticipated losses from the FMD outbreak in spring 2012, loss estimate from 550,000 head to 340,000 head (includes losses from FMD and other factors).

Indirect impact of the disease on the national economy:

This disease decreases milk production, impedes weight gain, hampers reproductive efficiency, and has a high mortality rate among young stock. Unchecked, FMD could exacerbate economic instability in the agricultural sector during the current period of tenuous economic growth.

According to the CIA, agriculture accounts for $14.5 \%$ of Egypt's gross domestic product (GDP). It ranks third after industry $(37.6 \%)$ and services $(47.6 \%)$ as the most important sector of the economy. About 32 percent of the labor pool engages in farming, with many others in the processing or trading of agricultural products. 


\section{I- HAZARD IDENTIFICATION}

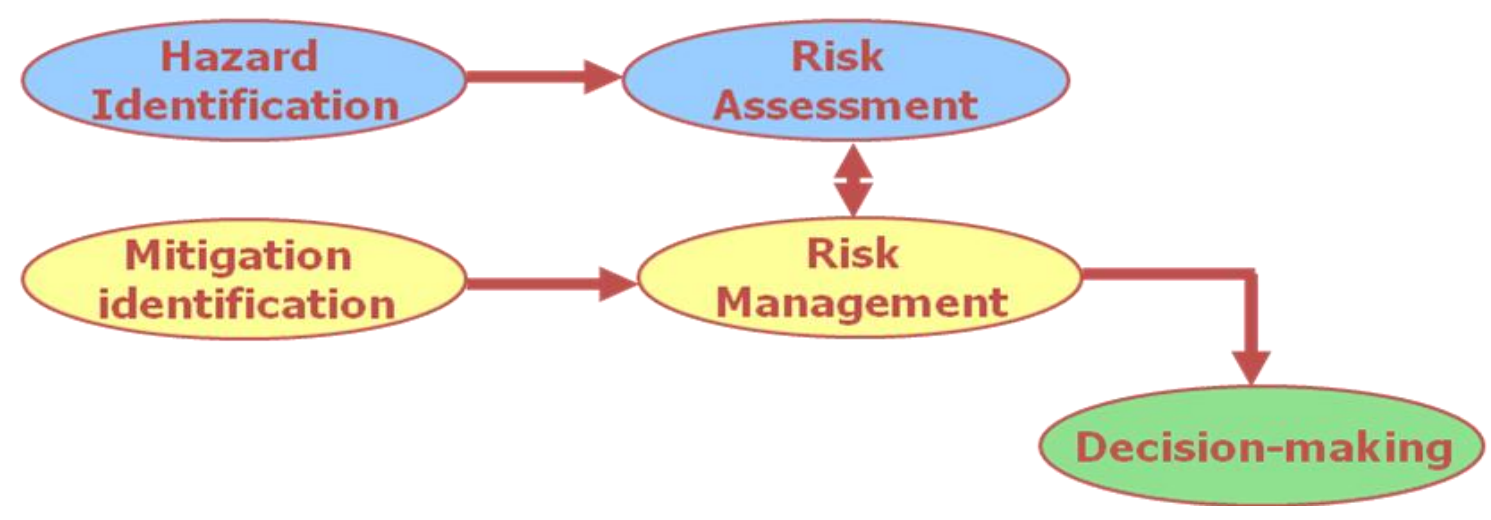

According to the (OIE, 2004), hazard identification is defined as "The hazard identification involves identifying the pathogenic agent which could potentially produce adverse consequences associated with the importation of a commodity" (OIE, 2004).

\section{Live Cattle Imports:}

Gain Report (2012) estimates that live cattle imports will increase to 100,000 head in MY 2013, up 5,000 head or 5 percent compared to the MY 2012 level. The bulk of these animals will originate in Sudan and Ethiopia for immediate slaughter. High international feed prices will tend to hinder some imports of feeder and dairy cattle. Australia, Brazil, Sudan, Ethiopia, and Croatia are the main source for Egypt's live cattle supply in MY 2013.

\section{Live Cattle Slaughter Operations:}

Based on decisions of the Egyptian veterinary authorities' slaughter of imported live cattle is only permissible at ports. Other slaughter facilities in Egypt are only for domestic slaughter. Portside slaughter facilities' processing capacity is low and inadequate for handling the high volume of imported animals. Port facilities also lack the necessary equipment for removing specified risk materials. Egypt only permits the import of animals 18 monthsof-age or younger for fattening and 24 month-old animals for slaughter prior to reaching 30 months-ofage.

\section{Sudanese Live Cattle Imports:}

Sudan enjoys abundance in livestock around 41.3 millions of cattle (African Development Bank Group, 2010) it can meet the Egypt demand for meat which has reached 1,000 tons per day.

\section{Why Sudanese cattle?}

Sudanese meats enjoy preferential characteristics for their good taste and acceptability among Arab consumers particularly that they reach the consumers fresh and safe not to mention the Islamic way of slaughtering of the animals. Additionally, the Sudanese animals feed on natural pastures with less amounts of fat and above all else they are geographically closer to the Arab markets. So far Sudanese cattle are not given growth-enhancing hormones or animal bi-products. Neither is Sudanese cattle fed on anti-biotics and hormonal implants like most American and European cattle.

In 2012, the Egyptian Ministry of Agriculture and Land Reclamation resumed the importation of live cattle for immediate slaughter from Sudan. Sudaneseorigin cattle is held in quarantine for 21 days under the supervision of Egyptian Quarantine Veterinarians in the Sudanese city of Wadi Halfa (bordering Egypt) and then ferried down the Nile to the city of Abu Simbel in Aswan (Upper Egypt) for immediate slaughter. The current market price for Sudaneseorigin beef sold in MALR outlets is LE 35-38 (\$5.706.19) per kilogram. The Ministry of Agriculture and Land Reclamation seeks to import 3,000 head of Sudanese cattle per month to rein in escalating domestic beef prices. The average weight of the imported Sudanese cattle for immediate slaughter is 350-450 kilogram per head, which produces about 210-270 kilograms of meat per head. On August 26, 2012, the Egyptian MALR signed a Memorandum of Understanding with Sudan's Ministry of Agriculture and Livestock establishing a farm for livestock production in Sudan. The 250 feddan (equivalent to 259.5 acres) farm site will provide the Egyptian market with 4,000 head of cattle and 4,000 head of sheep every 70 days. The Egyptian side will cover the technical expertise costs, while Sudan will assume housing and land rental costs (Gain Report, Global Agricultural Information Network, 2012).

\section{Epidemiological situation of FMD in Sudan:}

FMD is endemic in Sudan and it is reported almost every year. The following serotypes of FMD were reported in the Sudan: O, A, SAT 1 and SAT 2. Type $\mathrm{O}$ is the most widespread and most endemic. Types A and SAT 1 are sporadic, whereas type SAT 2 was only reported once (Abou El-Zein, 1983 and EuFMD, $2012 \mathrm{a}$ and $\mathrm{b})$. 
Prevalence of FMDV serotypes in different animal species (Habiela et al., 2010)

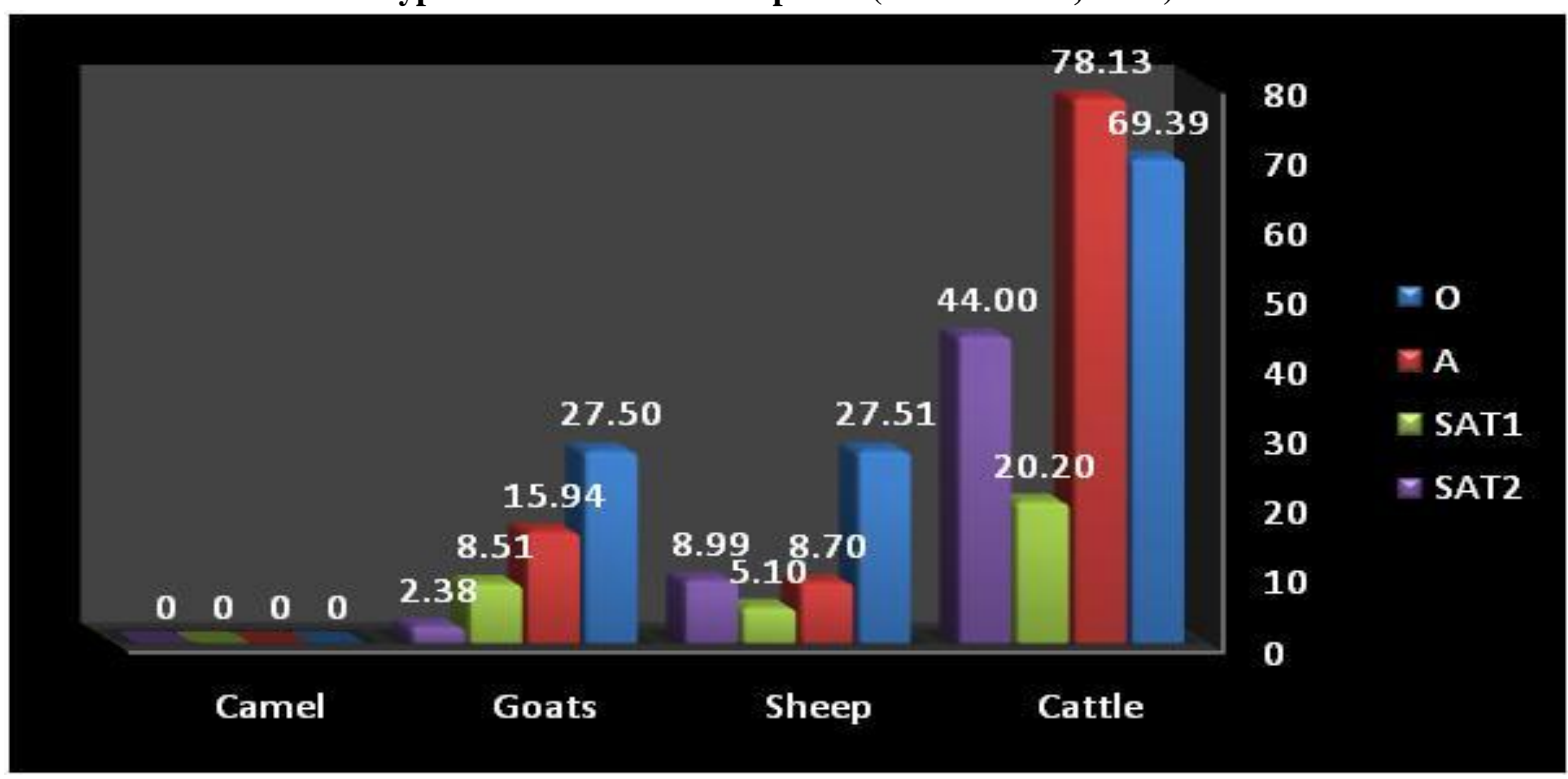

\section{Pattern of animal movement in Sudan}

With the exception of few intensive farms, livestock in the Sudan is reared under nomadic conditions, experiencing extensive movement for pastures and water. The free animal movement together with the lack of vaccination has played a great role in the spread of the disease in the Sudan. According to the official categorization, the exported calves come from South Kordufan, Darfur in western Sudan and Butana, in central eastern Sudan, regions. The exported types include Nyala and Mesariah types.

\section{Etiology:}

The FMD virus is a member of the Aphthovirus genus of the family Picornaviridae. The virion is nonenveloped, about $25 \mathrm{~nm}$ in diameter, and has an icosahedral symmetry. It contains a molecule of single-stranded RNA and 60 copies of each of the four structural polypeptides (VP1, VP2, VP3 and VP4). Of these, VP1 contains antigenic determinants that are important in stimulating neutralizing antibodies in infected hosts. There are seven serotypes of FMD virus - A, O, C, SAT 1, SAT 2, SAT 3 and Asia 1 (Logan et al., 1993).

\section{Virus Survival and resistance:}

The virus is most stable at $\mathrm{pH} 7.2-7.6$ but will survive at $\mathrm{pH} 6.7-9.5$, if the temperature is reduced to $4{ }^{\circ} \mathrm{C}$ or lower it will approximately survive 12 hours at $\mathrm{pH} 6.5,1$ minute at $\mathrm{pH} 6$, and 1 second at $\mathrm{pH}$ 5 Bachrach et al. (1975). Raising the temperature reduces the survival time. At temperatures below freezing point, the virus is stable almost indefinitely. Exposure to $56{ }^{\circ} \mathrm{C}$ for 30 minutes is sufficient to destroy most strains. Sunlight has little or no direct effect on infectivity; any loss of infectivity is due to secondary drying and temperature. The survival of airborne virus is mainly influenced by $(\mathrm{RH})$, with good survival above $60 \% \mathrm{RH}$ and rapid inactivation below 60\% RH (Donaldson, 1987).

Virus Infectivity (OIE, 2002)

- Infective dose for different routes

\begin{tabular}{lll}
\hline Species & Respiratory & Oral \\
\hline Cattle & $10-1000$ & 3 million \\
\hline Sheep & $15-100$ & Not known \\
\hline Pigs & 400 (approx) & 10 \\
\hline
\end{tabular}

\section{Factors influencing transmission:}

The extent to which FMD might spread depend on climatic factors, the efficiency of detection and diagnosis of early cases, livestock movements and density, biosecurity practices, animal management and marketing, and, possibly, the presence of feral and native animals. Movement of infected animals is widely recognized as one of the most important routes of FMD spread from one premises to another.
However, under favorable climatic conditions, movement of airborne virus particles to other properties by wind can be an important factor in FMD epidemics.

\section{Susceptible hosts:}

Cattle, water buffaloes, pigs, sheep, goats and deer are susceptible to FMD; the disease is generally most severe in cattle and pigs. Camelidae (camel and 


\section{Reviewer article}

llamas) have a low susceptibility (PAHO/WHO, 1995 and Sutmoller et al., 2003). Wild cloven-hoofed species are susceptible. Though rare, FMD in elephants, hedgehogs and some rodents has been documented. African buffaloes (Syncerus caffer) commonly become infected with FMD virus of the SAT serotypes, although clinical disease is rarely if ever observed.

\section{Host factors}

Species differ in their likelihood of infection with FMDV, their susceptibility to infection by different routes, and the amount of virus subsequently shed. Cattle, sheep and goats Because of their higher respiratory tidal volume, cattle are more susceptible to aerosol infection than sheep or pigs - sheep have one-quarter, and pigs one-twelfth, the infection risk of cattle. Cattle are considered the best indicator species for the presence of FMDV in an area. Larger cattle herds are more likely to be infected than smaller ones because of the greater probability that at least one animal will inhale an infectious dose (Donaldson 1987).

\section{Incubation period:}

The length of the incubation period for FMD is highly variable. It depends on the strain and dose of virus, the route of transmission, the animal species involved, individual susceptibility and immune status, and the husbandry conditions. Essentially, the higher the dose or intensity of contact, the shorter the incubation period. With natural routes and high doses of exposure, the incubation period can be as short as 2-3 days; it can be up to 10-14 days with very low doses (Donaldson 1987). When spread is occurring within a herd or flock, the typical incubation period is 2-6 days. For between-farm spread, it is more likely to be 2-14 days (Defra, 2006).

\section{Environment}

FMDV can remain infective in the environment for several weeks and possibly longer in the presence of organic matter, such as soil, manure and dried animal secretions, or on chemically inert materials, such as straw, hair and leather. Reported survival times of FMDV under various conditions include: up to 50 days in water (Mahnel et al., 1977). Up to 74 days on pasture at $8-18{ }^{\circ} \mathrm{C}$ and high relative humidity (MaCleod et al., 1992) and 26-200 days in soil, sacking, hay or straw, depending on storage or climatic conditions (Morgan, 1993 and Animal Health Australia 2012).

\section{Biosecurity:}

- Movement controls, quarantine measures, public notices or biosecurity in place and awareness of the need for biosecurity to prevent spread by farmers or veterinarians

\section{Modes of transmission:}

FMD is one of the most contagious animal diseases. FMD virus can be transmitted by direct or indirect contact or by aerosol. Fomites such as feed, drinking water, tools, animal products, as well as human clothing, transportation vehicles, rodents, stray dogs, wild animals and birds can transmit FMD over long distances. Virus is excreted in large quantities in expired air, in all secretions and excretions (including milk and semen) and from ruptured vesicles. Pigs excrete about 1000-3000 times more viruses in expired air than ruminants (Mann and Sellers, 1990; Thomson, 1994).

\section{Animal products and byproducts Meat and milk}

Many FMD outbreaks have originated from swill feeding of pigs with infected animal products, or meat scraps and bones from infected animals. Uncooked garbage from foreign ships has been a source of FMD in pigs. FMD virus can survive in frozen and contaminated meat in non-acid environments for up to 80 days. Therefore, APHIS considered presence of FMD virus in meat as a potential hazard (CEAH 2001). Unpasteurized raw milk and milk products from infected animals can contain considerable quantities of FMDV (Donaldson, 1997).

\section{Wool, skins and hides}

Due to the persistence of the virus on untreated wool, skins and hides, it would be possible for FMD to be transmitted to susceptible animals coming into contact with these products (WHO, 2010).

\section{Forage, grain and water}

Animals, especially pigs, might become infected by ingestion of contaminated forage, grain, animal products or water, or by licking contaminated objects (Sutmoller et al., 2003).

\section{Equipment and personnel}

FMDV can be readily spread on contaminated vehicles and equipment, and people can easily transfer infection to animals via contaminated boots, hands and clothing. Spread has been associated with veterinarians, vaccinating teams and rodent exterminators (Mann and Sellers, 1990; Thomson, 1994).

\section{Windborne spread}

Under suitable conditions, windborne spread could be involved in the transmission of FMD over several kilometres (Donaldson 1983; Garner and Cannon 1995). Windborne spread is a complex phenomenon and is affected by: The strain of virus, its ability to survive outside the host, and its shedding by the host species. A highly concentrated source of virus - this depends on the species, animal density and the stage of disease in the infected animals. Presence of suitable atmospheric conditions, including steady wind speed and direction, high relative humidity, temperature inversion, and low temperatures and sunlight; favorable conditions may be more likely to occur over water, - Local topography and terrain, 
density and susceptibility of animals in the exposed area downwind; cattle are most susceptible to infection by windborne spread because of their large tidal volume

\section{Routes of Infection:}

Animals are infected via ingestion, inhalation and natural or artificial insemination. The primary route of infection of ruminants is inhalation of contaminated aerosols, whereas pigs are mainly infected through ingesting contaminated feedstuff. Infected, preclinical animals can excrete large amounts of virus. Excretion in semen and milk can occur for up to 4 days before clinical signs appear. Sheep excrete virus in their breath for around 24 hours before signs are apparent (Burrows 1968). High titres of FMDV have been found in such animals. This is of great epidemiological importance. Clinically affected animals also shed large quantities of virus. Virus excretion from most sites diminishes rapidly with the appearance of circulating antibodies. Most excretion of virus ceases within 6 days of appearance of vesicles.

\section{Differential diagnosis:}

In cattle and pigs, the clinical signs of FMD are indistinguishable from those of vesicular stomatitis, and in pigs from those of swine vesicular disease and vesicular exanthema.

\section{Laboratory diagnosis}

Laboratory confirmation of a presumptive diagnosis of FMD depends upon isolation of the virus, detection of viral antigen or detection of antibodies. Detailed instructions for laboratory diagnostic procedures for FMD are to be found in the Manual of standards for diagnostic tests and vaccines (OIE, 2000). The following is a summary, with emphasis on tests that are usually used.

\section{Scenario Analysis:}

The following scenario describes the probability of introduction of new serotype of FMD to Egypt through imported cattle from Sudan: Prevalence of FMDv serotype SAT1 among cattle in Sudan is $20.20 \%$ according to the European Commission for the control of Foot and Mouth Disease (2012 a). The annual No. of imported cattle from Sudan to Egypt is about 20,000 head.

The scenario tree for the risk pathway is designed according to (Yu et al., 1997).

\section{Risk pathway of introducing exotic FMD virus serotypes via importation of cattle from Sudan to Egypt for Slaughter}

Is there an outbreak of FMD due exotic subtypes in the Sudan?

Are animals collected from FMD SAT1 free zones?

Are animals collected from various localities in the exporting country?

Are all collected animals vaccinated against SAT1 serotype?

Are the infected animals detected by animal health system during viraemia?

Are the selected animals are subjected to serological testing?

Are selected animals subjected to strict quarantine measures before shipment from the export country?

Are all shipped cattle slaughtered at the port of entry?

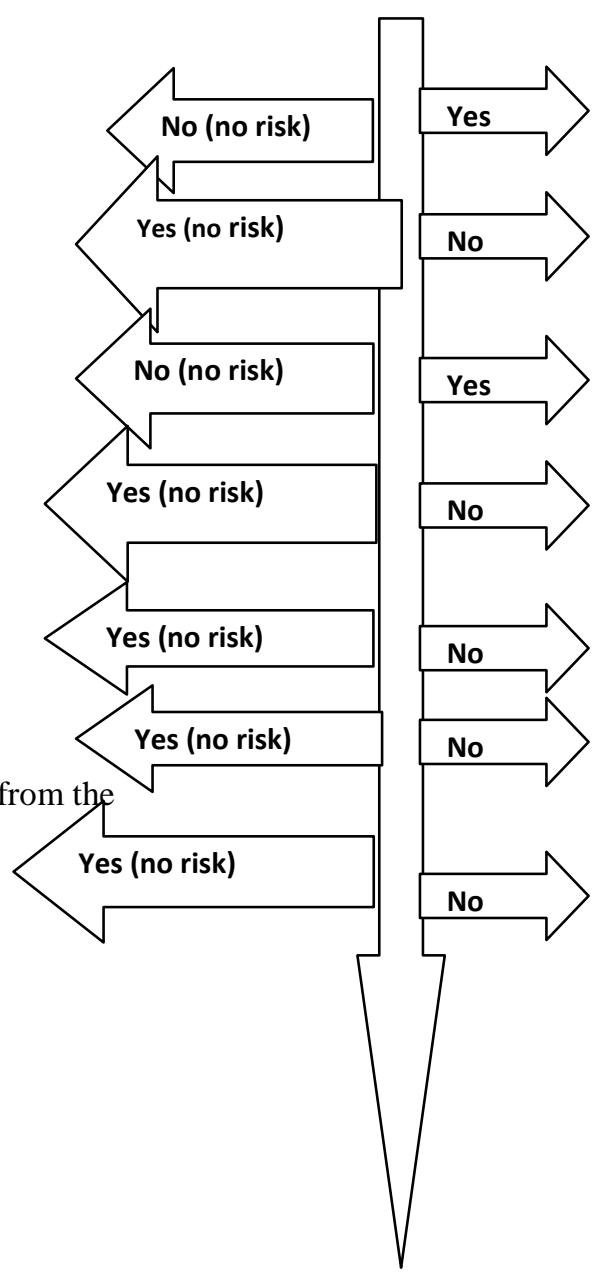




\section{Reviewer article}

The model was run 10,000 times using a Monte Carlo approach implemented on a commercial software (@Risk version 4.5.5 and Precision Tree version 1.0.9, Professional Edition, Palisade Corporation, 1996-2007) on Microsoft Excel (Microsoft1 Office Professional Edition, 2003). Maps displaying the risk of FMDV new strain introduction to Egypt through

@RISK Output Report for At least one infected animal entering Egypt / distribution Performed

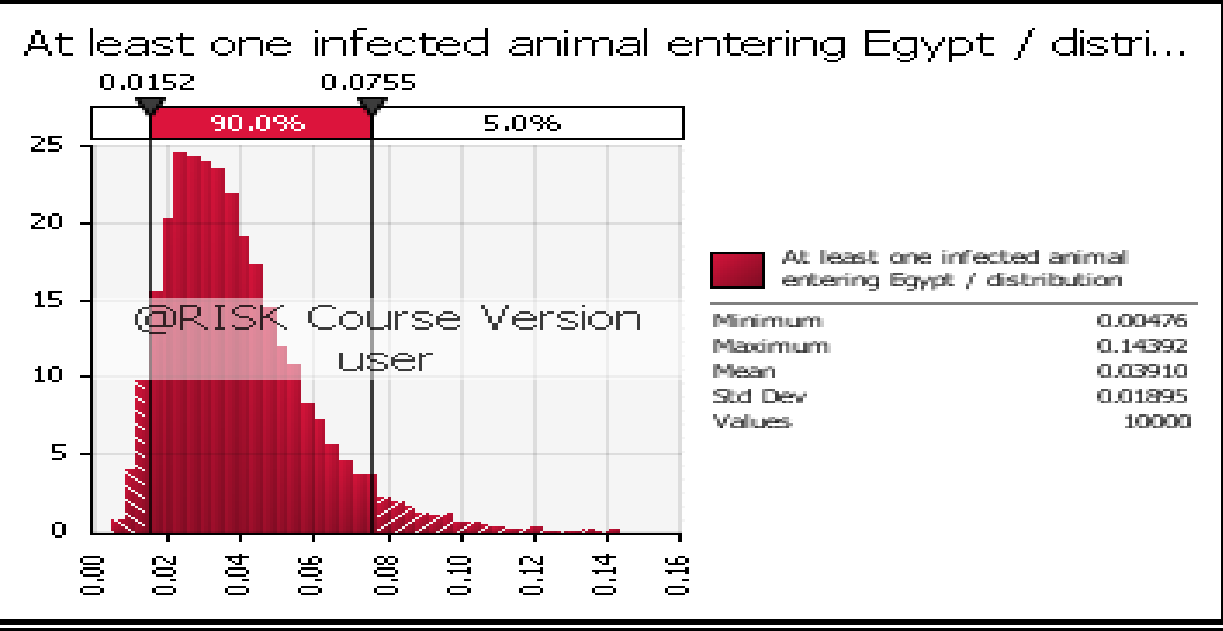

At least one infected animal entering Egypt / distri... Inputs Ranked by Effect on Output Mean

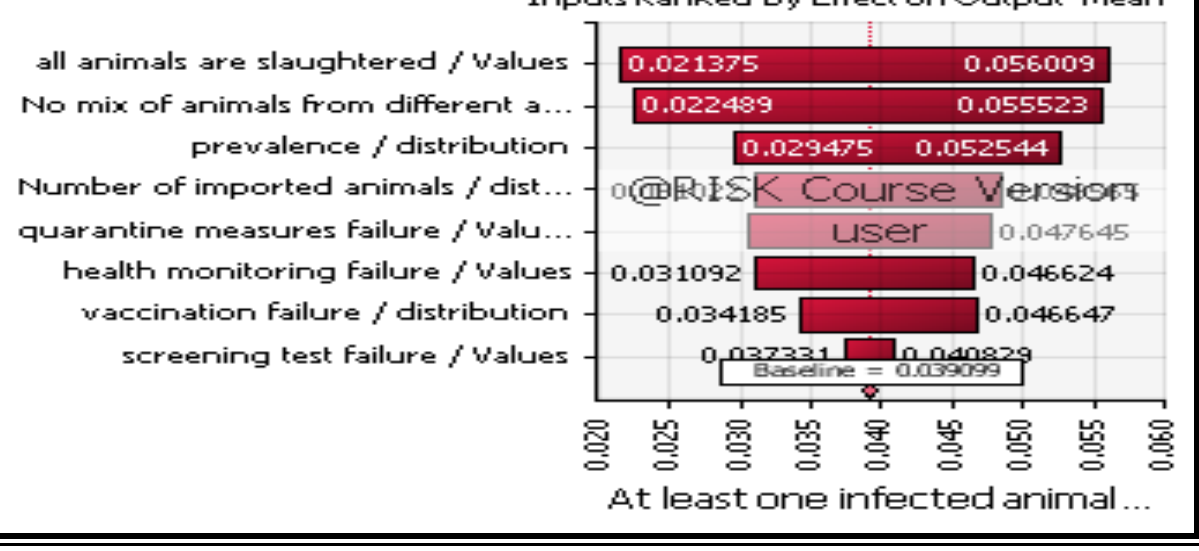

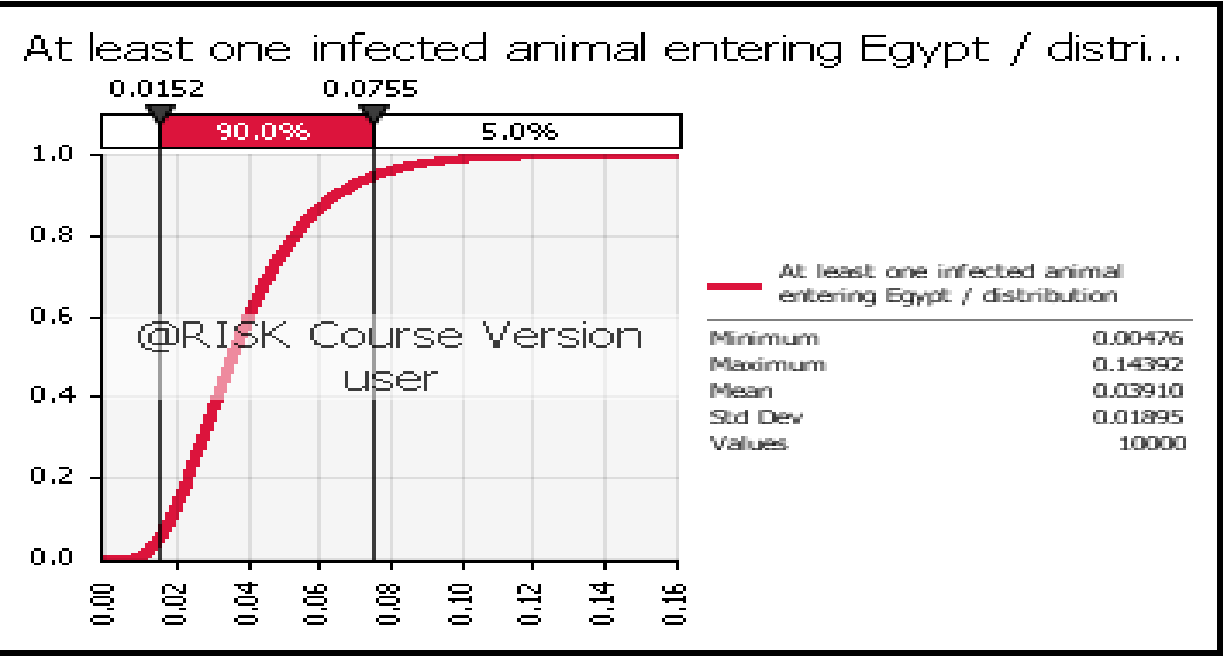


Among 20000 imported cattle from Sudan, at confidence levels between (5\% and 90\%) there is a probability of introducing 75 infected animal with a new strain of FMD virus or 3.75 infected animal among 1000 imported animal which represent low risk under the explained risk management measures.

\section{Risk mitigation pathway}

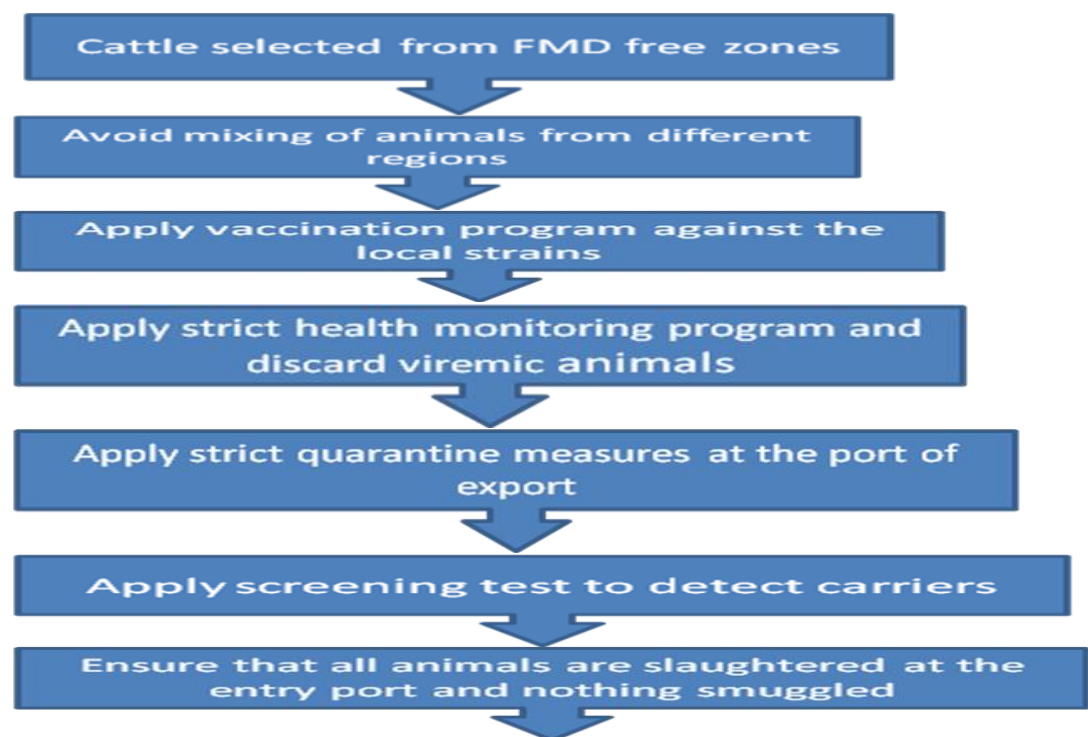

(If no animals are smuggled to Egypt, the risk of introducing a new serotype of FMDv, from Sudan will be minimal).

\section{Risk Management:}

Sanitary and Phytosanitary Standards develop an internationally credible program for certifying that Sudanese livestock exports have no or acceptably low risk of introducing trans-boundary animal diseases, such as FMD, into the importing countries.

OIE Recommendations on Trade in livestock:

One way to facilitate livestock exports from countries that are not FMD-free is to establish one or more FMD-free zones in which animals are completely segregated from those in adjoining infected zones (Scott et al., 2006)

1- Source of cattle: Exported animals should be selected from regions free from disease and vaccinate with FMD

2- Avoid mixing animals with others from FMD infected zones.

3- Vaccination: The protective effect of vaccination with an efficient vaccine, applied according to acceptable international standards will very significantly reduce the probability of animals becoming infected and thereby reduce the risk of infective animals being presented for slaughter.

4- Application of strict health monitoring system for detection of viremic cattle. Surveillance programmes need to be designed according to the disease situation in the country of origin (Animal Health Surveillance)

5- Application of approved screening test to detect carrier cattle before export.
6- Quarantine: A 3 week pre-slaughter quarantine will be a valuable mitigation measure providing that undetected infection of cattle does not occur during quarantine.

7- Slaughtering of all imported cattle at the nearest slaughter house at the port of entry

\section{Risk communication:}

Adequate risk communication is essential in explaining official policies to the importers, stakeholders and the public) who are often aware of the benefits but not the risks of importations. Risk communication must also be a two-way process, with the concerns of importers and stakeholders being heard by officials and addressed adequately.

\section{Acknowledgement:}

The author gratefully acknowledges the (USDA/APHIS-ITRCP) for funding and technical assistance of this edification article together with the Team of Center for Computational Epidemiology, Bioinformatics and Risk Analysis (CCEBRA), College of Veterinary Medicine, Nursing and Allied Health, Tuskegee University, USA.

\section{REFERENCES}

Abd El-Hakim, U. and Abd El-Rahim, I.H. (2000): An outbreak of Foot and mouth disease in Egypt in 1998: The need of reevaluation of vaccination program against foot and mouth disease in Egypt. Assuit. Vet. Med. J., 44:122-138. 


\section{Reviewer article}

Abu El-zein, E.M.E. (1983): Foot and mouth disease in the Sudan. Rev. Sci. Tech. Off. Int. Epiz., 2 (1), 177-188.

African Development Bank Group (2010): Regional Study on the sustainable Livestock development in the greater horn of Africa. Main Synthesis Report. Volume 1.

Animal Health Australia (2012): Disease strategy: Foot-and-mouth disease (Version 3.3). Australian Veterinary Emergency Plan (AUSVETPLAN), Edition 3, Standing Council on Primary Industries, Canberra, ACT: www.animalhealthaustralia.com.au

Bachrach, H.L.; Breese, S.S.; Callis, J.J.; Hess, W.R. and Patty, R.E. (1975): Inactivation of footand-mouth disease virus by $\mathrm{pH}$ and temperature changes and by formaldehyde. Proceedings of the Society for Experimental Biology and Medicine 95, 147-52.

Bartels, C. and Ryan, E. (2012): Rapid Assessment Mission Report On Foot-and-Mouth Disease Management in Egypt. FAO/EuFMD.

Berrada, J. (2012): Regional status and FMD'S control strategies in North Africa. FAO/OIE Global Conference on Foot and Mouth Disease Control. Bangkok, Thailand, 27-29.

Burrows, R. (1968): Excretion of Foot-and-Mouth disease virus prior to the development of lesions. The Veterinary Record, 82, 387-388.

CEAH (2001): Pathway assessment of foot-andmouth disease (FMD) risk to the United States: an evaluation in response to international FMD outbreaks in 2001. Centers for Epidemiology and Animal Health USDA-APHIS-VS.

Daoud, A.; Omar, A.; El-Bakry, M.; Metwally, N.; Mekkawi, M. and El-Kilany, S. (1988): Strains of foot and mouth disease virus recovered from 1987 outbreak in Egypt. J. Egypt. Vet. Med. Ass., 48 (1): 63-71

DEFRA (2006): Disease control: Biosecurity http://www.defra.gov.uk/Animalh/ diseasaes/control/biosecurity/ index.htm. [Accessed 17-Sep-06]

Donaldson, A.I. (1983): Quantitative data on airborne foot-and-mouth disease virus: its production, carriage and deposition. Philosophical Transactions of the Royal Society of London B302, 529-34.

Donaldson, A.I. (1987): Foot-and-mouth disease: the principal features. Irish Veterinary Journal 41: 325-327.

Donaldson, A.I. (1997): Risks of spreading foot and mouth disease through milk and dairy products. In Contamination of animal products: prevention and risks for animal health ( $P$. Sutmoller, ed.). Rev. sci. tech. Off. int. Epiz., 16 (1), 117-124.

El-Nakashly, S.A.; Abu Zeid, A.A; Samira El-Kilany and Abdel Aty, M.M. (1996): Isolation and identification of FMDV during an outbreak of 1993 in Egypt. $7^{\text {th }}$ Sci. Cong., 17-19 November, Fac.Vet. Med., Assuit Univer., Egypt.

El-Trabili, M.M.; El-Shahidy, M.S.; Azab, A.M.; Abu El-Naga, H.I.; Abd El-Daiem, M.M.; Abdelwahab, S.A. and Fawzy, M. (2009): Serological and molecular diagnosis of FMDV isolates collected from four provinces of Egypt. Suez Canal Vet. Med. J, IVX (1): 33-43.

EuFMD European Commission for the Control of FMD (2012a): Foot and mouth disease situation. Food and Agriculture Organization of the United Nation Monthly Report, June, 2012. [http://oie.int/].

EuFMD European Commission for the Control of FMD (2012b): Foot and mouth disease situation. Food and Agriculture Organization of the United Nation Monthly Report, November, 2012. [http://oie.int/]

FAO regional representation for the Middle East, (2007): Situation of Foot and mouth disease (FMD) in the Middle East. Updated November 2007.

Gain Report: Egypt. Livestock and Products Annual (2012): USDA Foreign Agricultural Services, Global Agricultural Information Network.

Garner, M.G. and Cannon (1995): Potential for wind-borne spread of foot and mouth disease virus in Australia, Australian Meat Research Corporation, Sydney, pp 88.

Habiela, M.; Alamin, M.A.G.; Raouf, Y.A. and Ali, Y.H. (2010): Epizootiological study of foot and mouth disease in the Sudan: The situation after two decades. Veterinarski Arhiv 80 (1), 11-26.

Knowles, N.J; Wadsworth, J.; Scott, M.R.; Swabey, K.G.; El-Kholy, A.E.; Abd El-Rahman, A.O.; Soliman, H.M.; Ebert, K.; Ferris, N.P.; Hutchings, G.H.; Statham, R.J.; King, D.P. and Paton, D.J. (2007): Foot and mouth disease virus serotype A in Egypt. Emerg Infect Dis13: 1593-1596.

Logan, D.; Abu Ghazaleh, M. and Blackmore, W. (1993): Structure of a major immunologic site on foot and mouth disease virus. Nature, 362: 266-268.

Lockhart, C.; Sumption, K.; Pinto, J. and Lubroth, J. (2012): Foot and mouth disease caused by serotype SAT2 in Egypt and Libya. A regional concern for animal health in North Africa and the Middle East. FAO/EMPRES. 25:1-7.

MaCleod, N.C.M.; Grieg, A. and Nettlton, P.F. (1992): Foot-and-mouth disease: the risk for Great Britain after 1992. Vet. Rec.130: 543.

Mahnel, M.; Ottis, K. and Herlyn, M. (1977): Stability in drinking and surface water of nine virus species of various genera. Zentralblatt für Bakteriologie, 
Infekionskrankheiten und Hygiene, Erste Abteilung Originale 16B: 64-84.

Mann, J. and Sellers, R. (1990): Foot and Mouth Disease in Virus Infections of Vertebrates Vol. 3 (Ed) Z. Dinter and B. Morein. Elsvier Publications, NY. pp. 903-912.

Martinez-Lopez, P; Perez, A.M.; De la Torre, A.; Sanchez-vizcaino Rodríguez, J.M. (2008): Quantitative risk assessment of foot and mouth disease introduction into Spain via importation of live animals. Preventative Vet. Med. 86: 43-56.

Moussa, A.A.M.; Banoub, S.M.; El-Said, T.E.; Fahmy, F. and Bohm, H.O. (1974): Typing and subtyping of a strain of FMDV isolated from Sharquia province 1970. Arab Vet. Cong. Cairo. J. Vet. Med. Ass. 34(3-4): 413-419.

Morgan, I. (1993): Spread of foot-and-mouth disease. Review prepared for the Australian Meat Research Corporation, Sydney.

Morley, R.S. (1993): A model for the assessment of the animal disease risks associated with the importation of animals and animal products. Rev. Sci. Tech. Off. Int. Epiz. 12 (4), 1055-1092.

OIE (World organization for animal health) (2000): Foot and mouth disease, Chapter 2. 1. 1. In manual of standards for diagnostic tests and vaccine, $4^{\text {th }}$ Ed. Paris, 77-92.

OIE (World organization for animal health) (2002): International animal health code: mammals, birds and bees, 11th Ed. OIE, Paris, 512 pp.

OIE (World Organization for Animal Health). (2004): Handbook on Import Risk Analysis for Animals and Animal Products. Volume 1: Introduction and qualitative risk analysis. Volume 2: Quantitative risk assessment. OIE, 2004.

(PAHO/WHO) Pan American Foot and Mouth disease center \& Tuskegee University School of Veterinary Medicine (1995): Assessment of

\section{Reviewer article}

the risk of foot-and-mouth disease introduction into the CARICOM countries through the importation of meat from Argentina and Uruguay. Scientific and Technical Monograph Series No 19. ISSN 0101- 4897. RJ, Brazil.

Paton, D.C.; Sinclair, M. and Rodriguez, R. (2009): Qualitative assessment of the commodity risk factor for spread of foot-and-mouth disease associated with international trade in deboned beef. OIE ad hoc Group on Trade in Animal Products, 1-54.

Scott, A.; Zepeda, C.; Garber, L.; Smith, J.; Swayne, D.; Rhorer, A.; Kellar, J.; Shimshony, A.; Batho, H.; Caporale, V. and Giovannini, A. (2006): The concept of compartmentalization Rev. Sci. Tech. Off. Int. Epiz., 25 (3), 873-879.

Sutmoller, P.; Barteling, S.S.; Olascoaga, R.C. and Sumption, K.J. (2003): Control and eradication of foot-and-mouth disease. Virus Research. 91: 101-144.

Thomson, G.R. (1994): Foot and mouth disease. In Infectious diseases of livestock with special reference to Southern Africa (eds Coetzer J.A.W., Thomson G.R., Tustin R.C.), pp. 825852. Cape Town, South Africa: Oxford University Press.

Vose, D.J. (2000): Risk analysis: a quantitative guide, $2^{\text {nd }}$ Ed. John Wiley \& Sons, Ltd, Chichester, 418.

World Organization for Animal Health (2010): Terrestrial Animal Health Code, 19th Ed. OIE, Paris. Available at: www.oie.int/eng/normes/mcode/en_chapitre_1 8.5.htm\#rubrique_fievre_aphteuse (accessed on 20 November 2010).

Yu, P.; Habtermariam, T.; Oryang, D.; Nganwa, D.; Obasa, M. and Robnett, V. (1997): A risk assessment model for foot and mouth disease (FMD) virus introduction through deboned beef importation. Prev. Vet. Med., 30 (1), 49-59.

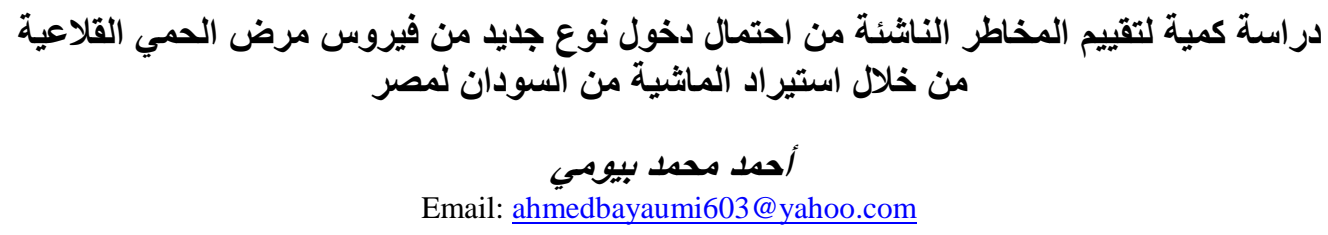

Email:ahmedbayaumi603@yahoo.com

مرض الحمى القلاعية مرض مستوطن بمصر ومستوطن بدولة السودان التى تتوطن بها الأنواع الآتيه من فيروسات الحمى القلاعية

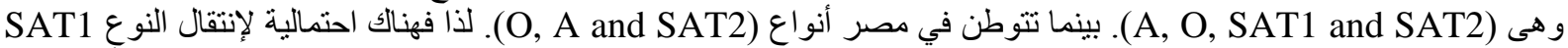

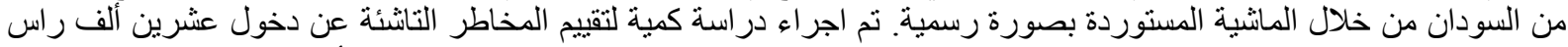

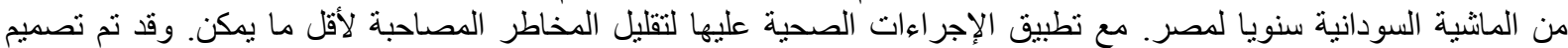

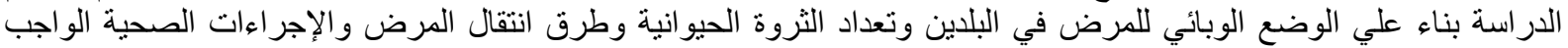

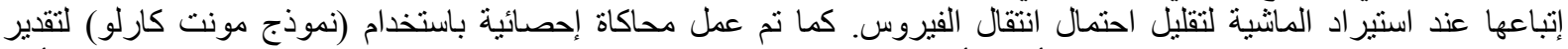

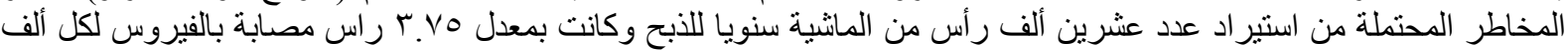

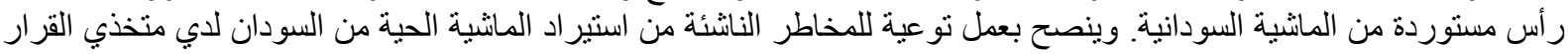

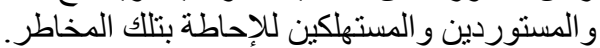

